\title{
Service Provided by the Elderly Person in the Family Health Strategy
}

Anna Cláudia Freire de Araújo Patrício1, Karoline de Lima Alves", Jiovana de Souza Santos ${ }^{2}$, Karla Fernandes de Albuquerque ${ }^{3}$, Valéria Peixoto Bezerra ${ }^{4}$, Maria Adelaide Silva Paredes Moreira5, Antonia Oliveira Silva ${ }^{6}$, Tatyanni Peixoto Rodrigues ${ }^{7}$

\section{Abstract}

Objective: Meet the care given to the elderly person in a unit of the family health strategy.

Method: Participated in 18914 elderly family health Strategies of João Pessoa-PB through a questionnaire, and the data processed by the software Statistical Package for the Social Sciences 19.0 and exposed in frequency and percentage.

Results: The elderly have in average of 68 years of age; majority $(66.3 \%)$ and married women (47.4\%). As for the service, most fully agrees with its resolution (67.1\%), occurrence of home visits $(80.4 \%)$, no long wait (40.2\%) and no other complaints (49.7\%). And However, $125(66.1 \%)$ of seniors disagree totally they receive priority assistance.

Conclusion: The care model of the family health strategy Unit is in line with most of its guidelines established

\section{Keywords}

Elderly; Attendance; The family health strategy.
1 Nurse. Graduate student at PPGENF, Universidade Federal da Paraíba. Member of the international group of studies and research in aging and social representations*

2 Nurse. Centro Universitário de João Pessoa. Member of the international group of studies and research in aging and social representations*.

3 Nurse. Doctor. Professor at the Centro Universitário de João Pessoa/UNIPÊ. Group of studies and research in aging and social representations*.

4 Nurse. Doctor. Professor of undergraduate and graduate degree in Nursing from Federal University of Paraíba, *

5 Physical therapist. Doctor. Professor of the graduate program in nursing, Federal University of Paraíba/PNPD, **

6 Nurse. PhD. Professor of undergraduate and graduate degree in Nursing from Federal University of Paraíba, **. Leader of the international group of studies and research in aging and social representations*

7 Nurse. PhD student. Member of the international group of studies and research in aging and social representations*.

*: GIEPERS. **: João Pessoa/PB, Brazil.

\section{Contact information:}

Jiovana de Souza Santos.

” jiovana_santos@hotmail.com

\section{Introduction}

The family health Strategy (FHS) was established with the objective of organizing the basic attention, expand access to health promotion and recovery, reducing hospital costs and directing for humanized 
assistance [1]. The dynamic organization advocated for the ESF is a challenge for managers and health professionals should promote full and continuous assistance to families who belong to the area, in all cycles of life, taking biopsychosocial aspects of the individual.

Thus, the ESF team must meet the changing profile of the population they serve, as the progressive increase of the elderly, due to the fall of fecundity and mortality reduction. For this layer of society requires special attention of health professionals that must execute the promotional actions assistance medical care or curative, promoting health and preventing disease, identifying the early damages [2].

The population aging changes the profile of illness of Brazilians and requires greater emphasis on prevention and treatment of chronic non-communicable diseases, presenting proposals to leverage policies that promote the health of the elderly population.

In order to promote targeted assistance to the elderly, the Ministry of Health implemented the National Health Policy of the elderly person, where claims that the ESF should be the preferred assistance level of care to the elderly [3]. In this sense, the team of the ESF should be able to provide integral attention to health of the elderly person belonging to their service area. Professionals should still offer the elderly and his family a humanized attention, including reception, orientation, monitoring and support at home.

For putting a humanized assistance, the ESF must plan and schedule actions to deal with the issues of the aging process and seek autonomy of users for self-care. These actions involve monitoring the fragile elderly people, know the habits of life, cultural, ethical and religious values of the elderly, their families and the community, offer continuing attention, develop and carry out health education activities of elderly person [3].

In this regard, health policies must help people reach old age with the best health possible. Active and healthy aging is the big goal in the process. We need to consider the health of larger form, it becomes necessary for any change in the current context towards the production of a more favorable social and cultural environment for the elderly [3].

The National Health Policy of the elder regulates and ensures social rights, creating conditions to promote their autonomy, integration and effective participation in society, reaffirming the right to health in the various levels of the single health system (SUS) [3], at which point the elderly care one aspect of fundamental importance to a quality healthcare.

Considering the progress of population aging in municipality of João Pessoa, considered by IBGE [4] the third city with the largest number of elderly and the first in the Northeast, making it important to undertake studies in the eyes of users, able to contribute to improving the care of elderly policies to offer a unique service and humanized. Soon, wonders what the opinion of the elderly on the care received in an ESF? To this end, this study aims to meet the care given to the elderly person in a unit of the family health strategy, in the eyes of the elderly.

\section{Methods}

This is an exploratory research, descriptive in nature with quantitative approach held in João Pessoa, Paraíba, Brazil, the Brazilian Northeast region.

Participated in the study, a 189 elderly population of 5000 people in this age group, attended by fourteen teams of the family health strategy, the district three, of the said municipality. The choice of this unit is justified because it is this unit located in a significant area of quantitative viewpoint of elderly. The sample was defined using the sample calculation with the Standisk Program version 11.1.0 resource USES, with the 95\% confidence level and $7 \%$ margin of error.

As a criterion for inclusion participants should own age less than 60 years; be registered in family health unit searched and who accept to participate 
voluntarily. Excluding all those who did not sign the informed consent form.

The data were collected during the period of February 2012 to March 2013 through a structured questionnaire, containing closed questions, divided into two parts: the first contemplated information on socio-demographic characteristics, and the second, contemplated items on the care offered in the family health Strategy where the study was conducted.

The instrument (questionnaire) structured contemplated items of questions and answers in the form of Likert type scale (5), with the following answers: I fully agree (CPL); I Agree Partially (CPA); Totally Disagree (DT); Disagree Partially (DPA); and, Neither Agree nor Disagree (N), tested previously, with members of the research group.

The questionnaire was applied to the seniors who attended the service during the collection period, being formalized with the signing of the informed consent Term and attendance to the ethical principles of the resolution 196/96 the National Health Council in force at the time (6). This study has received a favorable opinion by the ethics on Research
Committee of the Centro Universitário de João Pessoa with protocol number 08/2013.

The collected data were processed in the software Statistical Package for the Social Sciences (SPSS) 19.0, and analyzed from simple statistics noting the frequency and percentages.

\section{Results}

Of 189 elderly study, 66.3\% (126) are women, with an average of 68 years of age, with the majority (47.4\%) regarded as married and widows (28.9\%), with children (93.1\%), pensioners (51.1\%) and 30.0\% (57) with elementary schooling.

The National Policy of primary health care advocates that the ESF is the main port of entry to health care, it is important to know the service provided by the same through the opinion of users. In this way, it was evidenced that the elderly the study says so much so favorable and unfavorable, as neutral outside the service provided by the ESF's (Table 1 and 2).

Table 1. Service to seniors by the family health strategy-João Pessoa/PB, 2013. $(n=189)$.

\begin{tabular}{|c|c|c|c|c|c|c|c|c|c|c|c|c|}
\hline \multirow{2}{*}{ Items } & \multicolumn{5}{|c|}{ FA } & Total & \multicolumn{5}{|c|}{ FR (\%) } & \multirow{2}{*}{$\begin{array}{c}\text { Total } \\
\text { FR }\end{array}$} \\
\hline & CPL & CPA & DPA & DT & $\mathbf{N}$ & FA & CPL & CPA & DPA & DT & $\mathbf{N}$ & \\
\hline Attendance in Health Unit is resolute. & 121 & 46 & - & 21 & 01 & 189 & 64.0 & 24.0 & - & 111 & 0.5 & 100.0 \\
\hline $\begin{array}{l}\text { Waiting time to be served in the Health } \\
\text { Unit. }\end{array}$ & 76 & 42 & - & 71 & - & 189 & 40.2 & 22.2 & - & 37.6 & - & 100.0 \\
\hline $\begin{array}{l}\text { Receive medicines in this Health unit when } \\
\text { you need to. }\end{array}$ & 103 & 46 & - & 40 & - & 189 & 54.5 & 24.3 & - & 21.2 & - & 100.0 \\
\hline $\begin{array}{l}\text { Receives preferential service on this Health } \\
\text { Unit. }\end{array}$ & 58 & 06 & - & 125 & - & 189 & 30.7 & 3.2 & - & 66.1 & - & 100.0 \\
\hline $\begin{array}{l}\text { Have complaints about the care of the } \\
\text { Health Unit. }\end{array}$ & 94 & 17 & - & 74 & 04 & 189 & 49.7 & 9.0 & - & 39.2 & 2.1 & 100.0 \\
\hline Receive monthly visits. & 152 & 08 & - & 29 & - & 189 & 80.4 & 4.2 & - & 15.3 & - & 100.0 \\
\hline $\begin{array}{l}\text { There are architectural barriers from my } \\
\text { house to Health unit that hinder my access. }\end{array}$ & 130 & 23 & - & 36 & - & 189 & 68.8 & 12.2 & - & 19.0 & - & 100.0 \\
\hline
\end{tabular}

Source: survey data. Legend: FA = Absolute Frequency; FR $(\%)=$ Relative Frequency; $C P L=I$ Totally Agree; $C P A=\mid$ Agree Partially; DPA = Disagree Partially; DT = Strongly Disagree; $\mathrm{N}=$ Neither agree nor disagree. 
Table 2. Home visits conducted by health professionals of the ESF's. João Pessoa/PB, 2013. $(\mathrm{N}=189)$.

\begin{tabular}{|l|c|c|}
\hline \multicolumn{1}{|c|}{ Home Visits } & FA & FR (\%) \\
\hline Not receive home visits & 29 & 15.3 \\
\hline ACS & 154 & 81.5 \\
\hline ACS and Nurse & 2 & 1.1 \\
\hline Nurse & 1 & 0.5 \\
\hline ACS and Doctor & 1 & 0.5 \\
\hline ACS, nurse and Doctor & 2 & 1.1 \\
\hline Total & 189 & $100 \%$ \\
\hline \multicolumn{2}{|c|}{ Source: research data. Legend: FA = Absolute Frequency; } \\
\hline FR = Relative Frequency; ACS = Community Health Agent.
\end{tabular}

\section{Discussion}

The predominance of women in the studied Group confirms the process of feminization of old age and justifying the existence of the number of married women are greater than men, according to characteristics of the marital status of the Brazilian population (34.8\% married) identified in the Census (2010) [4].

The low educational level of the elderly is considered a meaningful indicator for show dimensions that must be observed in accordance with the recommendations in the elderly care policies as socioeconomic characterization of this population, as well as the social characteristic of the elderly group registered in the unity of the family health strategy, where the study was conducted, similar to the data found in the city of Guarulhos/São Paulo in 2009 [7], in that while most (57.9\%) was illiterate.

The elderly (67.1\%) agree fully that the attendance by the ESF is resolution, in which such positioning is relevant in the construction of a care model with planning and organization, identifying the health problems of the population.

In this sense, Brazil comes firming the consolidation of the ESF as the main entryway extending the efficaciousness of the services provided by primary care health and strengthening its coordinating role within the network of health services so that all of your users are met as advocates the guidelines of SUS in the attendance of the population [8].

Study of 70 elderly people in the city of João Pessoa-Paraíba, in 2010, in which evaluated the service offered to the elderly in the basic attention, it was observed that these elderly felt the ESF, good. However, the elderly in this study indicate the need to improve customer service, with greater participation of users in educational and health promotion to the elderly person [9].

As waiting for the elderly, on the one hand that $40.2 \%$ (76) agree that there is no delay in the ESF; on the other hand, $37.6 \%$ (71) of the elderly respondents disagreed entirely, demonstrating conflict of opinion on the waiting time for the service.

Important to consider that older people have their diminished physical ability, which favors a quick exhaustion while waiting in a queue to be served. This is one of the guarantees provided for in the Statute of the elderly [10], concerning the right of priority assistance and individualized, as the law 10,741/03.

The priority assistance in some regions of the country is not a reality (unanimous). Study of an elderly group in this age group, similar to the researched context, i.e. in a basic unit, the city of Paranavaí-PR, users claim that, despite the advances of the SUS, still face queues to receive care, causing many quit because expecting [11].

Thus, among the activities offered in the ESF is the host who aims to humanize the service, reshaping the work process, scoring problems and offering solutions and answers by identifying the demands of users, the service rearticulating around them [12]. Thereby, decreasing waiting of the elderly health services, since these are more fragile due to the process of senescence.

Questioned as to the provision of medicines to users by the ESF, 54.5\% (103) of the elderly agree fully that this need is not being met, although much of the older population has multiple chronic dege- 
nerative diseases, such as hypertension and diabetes that require the use of multiple medicines for better quality of life [13].

It is important to score the inaccessibility to medications for the control of these diseases can lead to worsening of the clinical picture of health and increased spending on secondary and tertiary assistance of SUS. Constitutes an aspect to be considered that many of the elderly by ESF have low monthly income, that is, the free supply of primary medicines, laid down in national politics of Medicines [14]. Therefore, it is incumbent upon the public authorities to provide medicines free of charge to elderly people, especially those of use still, besides the prostheses, orthoses and other resources relating to treatment, habilitation or rehabilitation, to do justice [10].

Study in Marilia/SP (2006) with 189 elderly linked to ESF points out that access to medicine was considered one of the difficulties reported, in particular, as to its use, in that and many elderly people need to perform the purchase despite the low socioeconomic condition, though, are not always available in public pharmacies [15].

Regarding lack of complaints about the attendance there was divergence of opinion among seniors studied, in which 49.7\% (94) agree fully and 39.2\% (74) disagree completely.

How to: quality, evaluation of health programs and services, user satisfaction checks that have generated important publications in the field of health, assistance for possible difficulties and pointing out the importance of social participation of the user in the effectiveness of health services and thus make planning actions to better watch the population [16].

In this context, the satisfaction of the users has been an increasingly important place in the evaluation of the quality of services, as it is directly related to therapeutic adhesion, better health care, and prognosis influencing health behaviors and disease [17].
Regarding architectural barriers recognized accessibility as an important aspect to be won, because those who have difficulties of access to the service in the ESF, demonstrated by $68.8 \%$ (130) of the elderly respondents to agree fully with your absence. It is important that access to health services is easy and secure, especially when watching much of the elderly population and this negligence implies possibility of falls.

Although the minority of elderly (36), i.e. 19.0\% point to the existence of architectural barriers that hinder access to the service, this fact deserves attention, since the demand for health services involves several factors that depend on how are made available may influence the choice of the user.

The efficaciousness of attention, conditions of access (distance from the Villa), steep topography (ravines and potholes, pavement inappropriate), time and cost of displacement, are some factors that handicaps the demand for services. Worldwide, the persistence of barriers in the process of search and use of the Services generates customized opportunities among social groups in obtaining health care, which often characterize situations of social injustice [18].

In assistance to the implementation of these actions and in service to the assumptions of the basic attention in health policy, it is recommended that the visible air delivery technologies incorporated as a systematic practice to be held by health professionals of the ESFs. Soon, the national primary health care Policy provides that all staff perform the adscrita population care, both within the framework of the services, such as from home and other community spaces [19].

It was observed that $80.4 \%$ (152) of the elderly respondents agree fully about the monthly visits to be carried out by the health services professionals, and frequently, however $15.3 \%$ (29) of seniors disagree entirely from coverage of the visit of the team.

In this sense, it is important to note that the home visit is an instrument of health care in which prio- 
ritizes the diagnosis of the reality of individual and educational actions. Therefore, an intervention is fundamental in family health and continuity of any form of assistance, being programmed and used in order to subsidize interventions or actions carried out by the professional planning of ESF [20].

It was identified that $15.3 \%$ (29) of the elderly reported that do not receive home visits from any professional in the ESF (Table 2). This fact has also been detected in another context by Oliveira e Menezes [21] in Natal/RN, where the elderly respondents reported to be rare to receive home visits from professionals of the ESF, justifying the absence of professional services load assigned to professionals, contrary to recommendations of Ordinance No. 2,488/2011, approved in the basic attention in Policy that establishes the frequency of home visits conducted by ACS, which are on average one every month [19].

It turns out that $81.5 \%$ of the elderly (Table 2) references the Community Health Agent (ACS) as the main ESF professional who performs home visits often. This importance of the ACS is configured as a response to his role in the team of professionals that generally focuses on the identification of demand on health education and monitoring of other health professionals, promotes community approach with ESF, discover and identify social and psychological situations critical to the process of care and that many times the health team is unaware of [22].

A study conducted with ACS in a ESF, the municipality of Volta Redonda/RJ points out that the actions of these professionals provide health promotion in the community and enable strategies to resolve or mitigate health problems (23).

Study by (24), with eight nurses and seven ESF CAs do Rio de Janeiro (2011), identified shortcomings in user interaction with the ACS, making the relationship and communication between the team. It also States that such a situation may interfere in the process of identifying the needs of the popula- tion during the home visits, because it is necessary that the information collected by ACS are passed on to the other professionals, with a view to the planning of actions.

The participation of nurses in demand of home visits was referred to by $1.7 \%$ (3) of the elderly, confronting with the provisions in its National Policy governed by the assignments of primary health care, in which recommends prevention activities and health promotion, through home visits, promoting educational activities individual and collective households and in the community [19].

The emphasis in this study the aspects associated with the House call was one of the concerns of both the Group of elderly people interviewed in this study, as in, a study performed with eight nurses who work addressing the House call in São Paulo health unit (2012), which highlighted the lack of understanding about the importance of home visit in the case of work of health professionals, they are made mechanically [25].

The nurse during the home visit should develop a specific assistance in the elderly care, prioritizing the care to the sick, bedridden or with some difficulty of locomotion, requiring health interventions [24].

\section{Conclusion}

This study sought to meet the service provided to the elderly by the family health strategy that were some weaknesses in some of their rights, as the attendance preferred, the difficult access to medicines in the ESF ' $s$, which counteract national health policy of the elderly person, which regulating their social rights, ensuring the completeness as well as the preferred host, which meet the criteria, ensuring the best quality services in health.

On the absence of complaints about the attendance there was divergence of opinion among the elderly when $49.7 \%$ (94) these agree fully and $39.2 \%$ (74) disagree completely. Turns on this divergence, the need for other studies that listen for 
the appreciation of the factors that contribute to satisfaction on the theme.

Although, on the one hand you have evidenced the presence of ACS during the home visits, on the other, registered deficit in visits by other professionals in the ESF, thus not valued the presence of health professionals about the importance of these visits in the planning of prevention and health promotion, according to the National Policy of basic attention, nurtured for direct contact with the community.

On this, it is observed that it is necessary to enhance the service for elderly person within the SUS, in which customers are met so singular in its fullness biopsicosioespiritual, i.e. the care the elderly person will require the provision of accessible services to behold its limitations and guarantees them a service, Humanized, and resolution of your needs.

It is essential that the multi-professional team that comprises the ESF remains always on the same page and search for the quality of the assistance provided, improving the health of seniors who meet, as these require more attention and follow-up by the health professionals, making the development of priority actions that prevent disease, and promote health rehabilitee [25].

Investigate complaints at health services contributes to its improvement, since the SUS is in constant development, and requires that its proposals envisaged in the policy will be fixed in a manner continued and basic health units.

\section{References}

1. Kerber NPC, Kirchhof ALC, Cezar-Vaz MR. Considerações sobre a atenção domiciliária e suas aproximações com o mundo do trabalho na saúde. Cad Saude Publica. 2008; 24(3): 485-93.

2. Coutinho AT, Popim RC, Carregã K, Spiri WC. Integralidade do cuidado com idoso na ESF. Esc. Anna Nery. 2013; 7(4): 628 -37.

3. Ministério da Saúde. Política nacional de atenção básica. Secretaria de Atenção à Saúde. Departamento de Atenção Básica. [Internet]. Brasília: Ministério da Saúde, 2006 [acesso em 23 abr. 2014]. Disponível em: http://bvsms.saude.gov.br/bvs/ publicacoes/politica nacional atencao basica 2006.pdf

4. Instituto Brasileiro de Geografia e Estatística [Internet]. Brasília: Censo Demográfico 2010 (BR). [Acesso em: 14 abr. 2014]. Censo Demográfico. 2010. Disponível em: http://biblioteca.ibge.gov. br/visualizacao/periodicos/99/cd 2010 resultados gerais amostra.pdf

5. Carifio J, Perla R. Resolving the 50-year debate around using and misusing Likert scales. Medical Education. 2008; 42(12): 1150-1152.

6. Resolução $n^{\circ} 196$ do Conselho Nacional de Saúde, de 10 de outubro de 1996 (BR). Aprova as diretrizes e normas regulamentadoras de pesquisas envolvendo seres humanos. Ministério da Saúde. Comissão Nacional de Ética e Pesquisa. Versão 2012 [acesso em: 13 fev. 2014]. Disponível em: http://conselho.saude.gov.br/web comissoes/conep/aquivos/ resolucoes/23 out versao final 196 ENCEP2012.pdf.

7. Santos GS, Teixeira MB. Diagnósticos de enfermagem frequentes em idosos residentes na área de abrangência de uma Estratégia Saúde da Família. REFACS. 2013; 1(1): 41-34.

8. Almeida PF, Fausto MCR, Giovanella L. Fortalecimento da atenção primária à saúde: estratégia para potencializar a coordenação dos cuidados. Rev. Panam Salud Publica. 2011; 29(2): 84-95

9. Mendes CKTT, Moreira MASP, Bezerra VP, Sarmento AMMF, Silva LC, Sá CMCP. Atendimento para idosos na Atenção Básica de Saúde: Representações Sociais. R. pesq. cuid. Fundam. 2013; 5(1): 3443-52.

10. Lei 10.741 , de $1^{\circ}$ de outubro de 2003. Estatuto do idoso, de 1 de outubro de 2003 (BR). Dispositivos Constitucionais Pertinentes. A garantia de prioridade Do Direito à Saúde. Senado Federal. Subsecretaria de Edições Técnicas. 1 de out 2003 [acesso em: 16 abri 2014]. Disponível em: http://www.inpas.rj.gov.br/inpas/ modules/xt_conteudo/content/Estatuto_Idoso.pdf.

11. Costa MAR, Cambiriba MS. Acolhimento em enfermagem: a visão do profissional e a expectativa do usuário. Cienc Cuid Saude. 2010; 9(3): 494-502.

12. Guedes MVC, Henriques ACPT, Lima MMN. Acolhimento em um serviço de emergência: percepção dos usuários. Rev. Bras. Enferm. 2013; 66(1): 31-7. 
v13. Santos TRA, Lima DM, Nakatani AYK, Pereira LV, Leal GS, Amaral RG. Consumo de Medicamentos por idosos, Goiânia, Brasil. Rev. Saúde Pública 2013; 47(1): 94-103.

14. Ministério da Saúde. Política nacional de medicamentos. Secretaria de Políticas de Saúde [Internet]. Brasília: Ministério da Saúde, 2001[acesso em: 28 abr. 2014]. Disponível em: http://bvsms.saude.gov.br/bvs/publicacoes/politica medicamentos.pdf

15. Marin MJS, Cecílio LCO. Necessidades de saúde de idosos de uma Unidade de Saúde da Família. Rev. Bras. Geriatr. Gerontol. 2009; 12(1): 76-63.

16. Brandão ALRBS, Giovannella L, Campos CEA. Avaliação da atenção básica pela perspectiva dos usuários: adaptação do instrumento EUROPEP para grandes centros urbanos brasileiros. Ciência \& Saúde Coletiva. 2013; 18(1): 103-14.

17. Albuquerque $A B$, Deveza M. Adesão ao tratamento na prática do Médico de Família e Comunidade e na Atenção Primária à Saúde. Promef-Artmed. 2009; 3(4): 41-72.

18. Siqueira FCV, Facchini LA, Silveira DS, Piccini RX, Thumé E, Tomasi E. Barreiras arquitetônicas a idosos e portadores de deficiência física: um estudo epidemiológico da estrutura física das unidades básicas de saúde em sete estados do Brasil. Ciência \& Saúde Coletiva. [Internet]. [Acesso em 23 abr. 2014]. 2014; 14(1): 39-44 Disponível em: http://www.scielosp.org/pdf/ csc/v14n1/a09v14n1.pdf.

19. Ministério da Saúde. Política Nacional da Atenção Básica. Secretaria de Atenção à Saúde. Portaria n 2.488 de 21 de outubro de 2011 (BR). 2011. Aprova a Política Nacional de Atenção Básica [Internet]. Brasília: Ministério da Saúde, 2011 [acesso em 23 abri 2014]. Disponível em: http://bvsms.saude. gov.br/bvs/saudelegis/gm/2011/prt2488_21_10_2011.html.

20. Oliveira LPBA, Menezes RMP. Representações de fragilidade para idosos no contexto da estratégia saúde da família. Texto Contexto Enferm. 2011; 20(2): 301-9.

21. Kebiani LVA, Acioli S. Visita domiciliar: espaço de práticas de cuidado do enfermeiro e do agente comunitário de saúde. Rev. enferm. UERJ. 2011; 19(3): 403-9.
22. Filgueiras AS, Silva ALA. Agente Comunitário de Saúde: um novo ator no cenário da saúde do Brasil. Physis Revista de Saúde Coletiva. 2011; 21 (3): 899-915.

23. Kebian LVA, Acioli S. A visita domiciliar de enfermeiros e agentes comunitários de saúde da Estratégia Saúde da Família. Rev. Eletr. Enf. 2014; 16(1): 161-9.

24. Santos EM, Morais SHG. A visita domiciliar na estratégia saúde da família: percepção de enfermeiros. Cogitare Enferm. 2011; 16(3): 492-7.

25. Bousquat A, Gomes A, Alves MCGP. Acesso realizado ao Programa de Saúde da Família em área com "alta" cobertura do subsistema privado. Ciência \& Saúde Coletiva. 2012; 17(11): 2913-21.
Publish in International Archives of Medicine

International Archives of Medicine is an open access journal publishing articles encompassing all aspects of medical science and clinical practice. IAM is considered a megajournal with independent sections on all areas of medicine. IAM is a really international journal with authors and board members from all around the world. The journal is widely indexed and classified Q1 in category Medicine. 